\title{
Meta Analysis the Effect of Physical Activity on Survival Life in Breast Cancer Patients
}

\author{
Enge Surabina Ketaren'), Bhisma Murti 1), Vitri Widyaningsih"2) \\ 1)Masters Progam in Public Health, Universitas Sebelas Maret \\ 2)Faculty of Medicine, Universitas Sebelas Maret
}

\section{ABSTRACT}

Background: Physical activity has a positive role in breast cancer risk. Physical activity intensity is often expressed as metabolic equivalents (METs) and the analytic guidelines for international physical activity questionnaires define low activity as 4 METs and high activity as 8 METs. This study aims to estimate the effect of physical activity on the survival of breast cancer survivors based on a number of previous similar studies.

Subjects and Method: This study is a systematic review and meta-analysis study. The articles used in this study were obtained from several databases including PubMed, Science Direct, Google Scholar, and Springer Link. The articles used in this study were those published from 2000-2020. The population in the study were breast cancer survivors with an intervention in the form of high physical activity. Comparison, namely low physical activity, and an outcome in the form of survival. Keywords for searching articles are as follows: "physical activity" AND "breast cancer survivors" AND "lifesustainability" OR "survival" AND "breast cancer" AND "adjusted hazard ratio" AND "cohort". The articles included in this study are full text articles with a cohort study design. Articles were collected using PRISMA flow diagrams. Articles were analyzed using the Review Manager 5.3 application.

Results: There were 8 articles originating from Denmark, Norway, Canada, Germany and the United States. The results of the meta-analysis showed that physical activity was statistically significant in increasing the survival of breast cancer survivors $(\mathrm{HR}=0.7495 \% \mathrm{CI}=$ 0.63 to $0.87 ; \mathrm{p}=0.0003$ ) and $\mathrm{I}^{2}=0 \%$.

Conclusion: High physical activity increases the survival of breast cancer survivors.

Keywords: High physical activity, survival, breast cancer survivors

\section{Correspondence:}

Enge Surabina Ketaren. Masters Progam in Public Health, Universitas Sebelas Maret. Jl. Ir. Sutami 36A, Surakarta 57126, Central Java. Email: ketarenenge3@gmail.com. Mobile: 087838583646.

Cite this as:

Ketaren ES, Murti B, Widyaningsih V (2021). Meta Analysis the Effect of Physical Activity on Survival Life in Breast Cancer Patients. Indones J Med. 06(01): 32-41. https://doi.org/10.26911/theijmed.2021.06.01.04.

(c) (7) (2) Indonesian Journal of Medicine is licensed under a Creative Commons

Attribution-NonCommercial-ShareAlike 4.0 International License.

\section{BACKGROUND}

Globally, about $63 \%$ of the causes of death in the world are caused by non-communicable diseases (PTM). Unhealthy lifestyles such as unhealthy diets, lack of physical activity and smoking can increase the prevalence of hypertension, diabetes, obesity, heart and blood vessel disease and various types of cancer which are the biggest causes of death (Ministry of Health of RI, 2017). In 2018, the number of new breast cancer cases was 2.1 million people (11.6\%) with the highest death of 626,679 people $(6.6 \%)$ worldwide. The highest number of cases of breast cancer is in Asian countries which was 911,014 people (43.6\%) per 100,000 population with the number of death by 310,577 people (49.6\%). There are two 
strategies for early detection of breast cancer, namely early diagnosis and screening. Therefore, early detection is needed to improve the survival of breast cancer survivors (Globocan Observatory, 2020).

Developments in cancer diagnosis and treatment have a profound impact on the survival of cancer survivors. The term "cancer survivor" is an individual who has a history of cancer from the time of diagnosis to the end of life (American Cancer Society, 2019). Cancer survivors are also expected to be able to maintain a balance in life (Speck et al., 2010). Physical activity is every movement of the body that is produced by skeletal muscles that require energy expenditure, such as walking, cycling, sports and recreation. The purpose of doing physical activity is to increase or maintain one or more components of physical fitness (WHO, 2020).

The 2008 physical activity guidelines from the United States Department of Health and Human Services recommends 2.5 hours per week (MET-hours/week) of moderate to high intensity activity to reduce the risk of all causes of death for coronary heart disease, stroke, hypertension, type 2 diabetes, excessive weight gain, falls with injuries to the elderly, breast, colon, endometrial, esophageal, kidney, stomach and lung cancer. Physical activity intensity is often expressed as metabolic equivalents (METs) and the analytic guidelines for international physical activity questionnaires recommend defining moderate activity as 4 METs and high activity as 8 METs. These values are consistent with physical activity guidelines which define 3 to 5.9 METs as moderate physical activity and $\geq 6$ METs as high physical activity (Beasley et al., 2012).

\section{SUBJECTS AND METHOD}

\section{Study Design}

This study used meta-analysis and systematic review. Articles conducted by the meta-analysis are available on data-based electronics at PubMed, Google Scholar, Springer Link and Science Direct.

\section{Inclusion Criteria}

The inclusion criteria in this study were English-language articles in full text, the study design used a cohort with multivariate analysis showing the results of Adjusted Hazard Ratio (aHR), articles published from 2000 to 2020 and breast cancer survivors (women) aged over 18 years old.

\section{Exclusion Criteria}

The exclusion criteria in this study were duplicate articles and articles that had been conducted by meta-analysis.

\section{Definition of Operational Variables} Physical activity is a body movement that can improve health and fitness. The instruments used were questionnaires and physical activity assessments MET h/week. Survival or life sustainability is a person's ability to survive. The instrument used was data on mortality from breast cancer. A breast cancer survivor is someone who is diagnosed with breast cancer based on a doctor's diagnosis.

\section{DataAnalysis}

Data analysis in this study was using RevMan 5.3 and the results of the analysis included in this study were using the Fixed effect model.

\section{RESULTS}

The process of searching for articles by searching through an article database which includes: PubMed, Springer Link, Science Direct and Google Scholar. Keywords used include: "physical activity" AND "breast cancer survivors" AND "life sustainability" OR "survival" AND "breast cancer" AND "adjusted hazard ratio" AND "cohort". 
Ketaren et al./ The Effect of Physical Activity on Survival Life in Breast Cancer Patients

The following are the search results for primary articles for the meta-analysis:

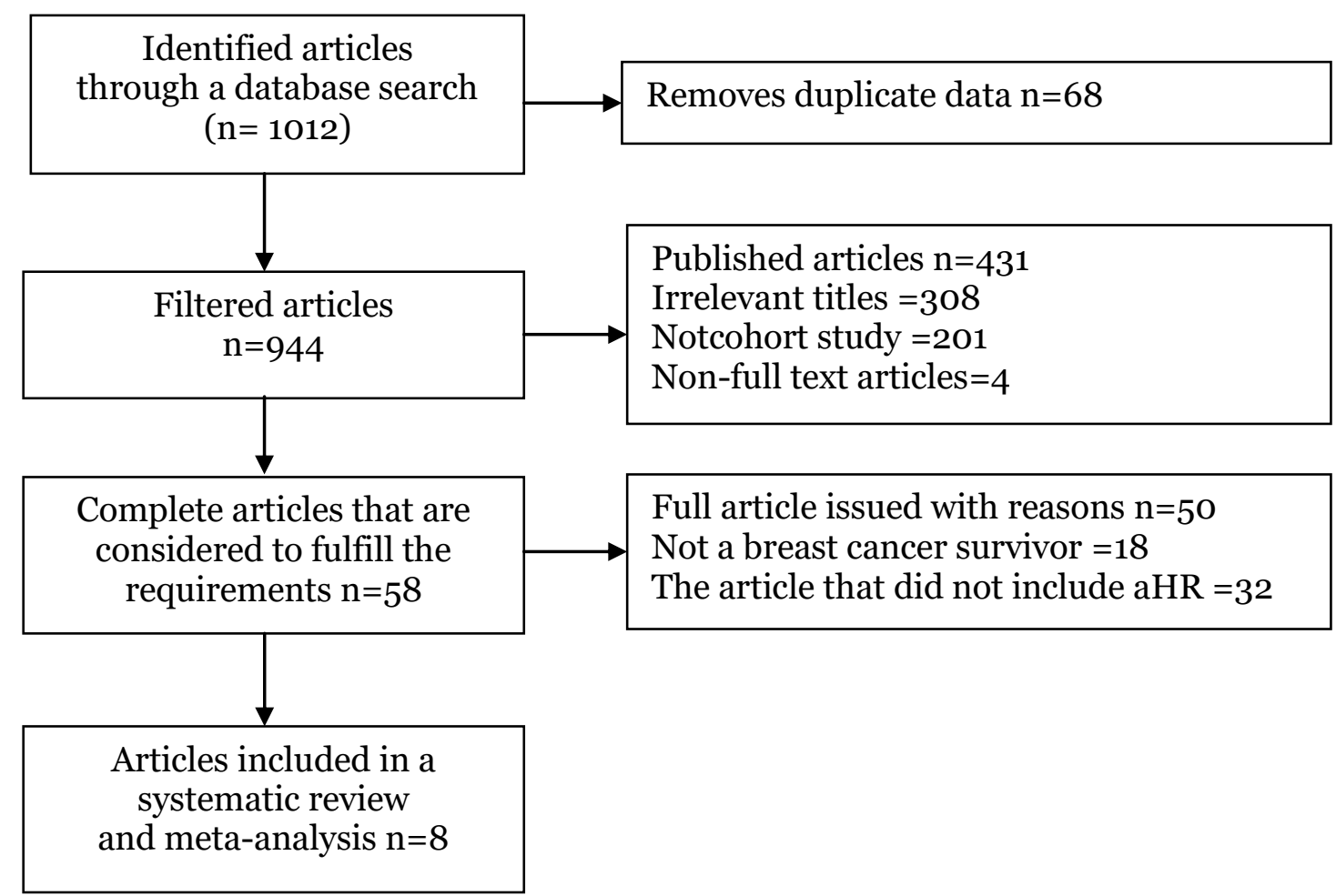

Figure 1. PRISMA flow diagram

The initial search process obtained 1012 article results, after the process of eliminating published articles, 944 articles were found, 58 of which fulfilled the requirements for further full text review. The results of the articles that fulfilled the qualitative requirements were reviewed again and 8 articles that fulfilled the quantitative requirements were high physical activity.

Articles that belong to the exclusion criteria are due to the following reasons:

1. The intervention from the cohort study was not physical activity in breast cancer survivors but other lifestyles such as smoking.
2. Did not include the aHR value from the results of multivariate logistic regression analysis.

3. Outcome is not survival (death) in breast cancer survivors but survival of endometrial cancer.

There are 8 studies related to the effect of physical activity on the survival of breast cancer survivors in various countries, namely Denmark, Norway, Canada, Germany, and the United States. An overview of primary study can be seen in Table 1. 
Ketaren et al./ The Effect of Physical Activity on Survival Life in Breast Cancer Patients

Table 1. Summary Sourceof the effect of physical activity on survival life of breast cancer survivors

\begin{tabular}{|c|c|c|c|c|c|c|}
\hline $\begin{array}{l}\text { Author, } \\
\text { year }\end{array}$ & Country & $\begin{array}{c}\text { Sample } \\
\text { size, } \\
\text { Age } \\
\end{array}$ & $\begin{array}{l}\text { Popula- } \\
\text { tion }\end{array}$ & $\begin{array}{l}\text { Intervention, } \\
\text { Comparison }\end{array}$ & Outcome & $\begin{array}{c}\text { Effect } \\
\text { HR } \\
\text { (95\% CI) }\end{array}$ \\
\hline $\begin{array}{l}\text { Ammitzboll } \\
\text { et al., 2016 }\end{array}$ & Denmark & $\begin{array}{l}959, \\
50-65 \\
\text { years old }\end{array}$ & $\begin{array}{l}\text { Breast } \\
\text { cancer } \\
\text { women } \\
\text { stage } \\
\text { I,II,III }\end{array}$ & $\begin{array}{l}\text { I: High physical } \\
\text { activity } \\
\text { C: Low physical } \\
\text { activity }\end{array}$ & $\begin{array}{l}\text { Breast } \\
\text { cancer } \\
\text { deaths }\end{array}$ & $\begin{array}{c}0.85 \\
(0.57- \\
1.29)\end{array}$ \\
\hline $\begin{array}{l}\text { Borch et al., } \\
2015\end{array}$ & Norway & $\begin{array}{l}1327, \\
\text { Mean } \\
53 \cdot 3 \\
\text { years old }\end{array}$ & $\begin{array}{l}\text { Breast } \\
\text { cancer } \\
\text { women } \\
\text { stage I-IV }\end{array}$ & $\begin{array}{l}\text { II: High physical } \\
\text { activity } \\
\text { C: Low physical } \\
\text { activity }\end{array}$ & $\begin{array}{l}\text { Breast } \\
\text { cancer } \\
\text { deaths }\end{array}$ & $\begin{array}{c}0.50 \\
\left(0.15^{-1.62)}\right.\end{array}$ \\
\hline $\begin{array}{l}\text { Maliniak et } \\
\text { al., } 2017\end{array}$ & USA & $\begin{array}{l}3689 \\
<65 \\
\text { years old }\end{array}$ & $\begin{array}{l}\text { Breast } \\
\text { cancer } \\
\text { women } \\
\text { stage IV }\end{array}$ & $\begin{array}{l}\text { II: High physical } \\
\text { activity } \\
\text { C: Low physical } \\
\text { activity }\end{array}$ & $\begin{array}{l}\text { Breast } \\
\text { cancer } \\
\text { deaths }\end{array}$ & $\begin{array}{c}0.49 \\
(0.26- \\
0.95)\end{array}$ \\
\hline $\begin{array}{l}\text { Sternfeld et } \\
\text { al., } 2009\end{array}$ & USA & $\begin{array}{l}1970 \\
\text { Mean } \\
60.4 \\
\text { years old }\end{array}$ & $\begin{array}{l}\text { Breast } \\
\text { cancer } \\
\text { women } \\
\text { stage } \\
\text { I/IIa/IIb/I } \\
\text { IIa }\end{array}$ & $\begin{array}{l}\text { I: High physical } \\
\text { activity } \\
\text { C: Low physical } \\
\text { activity }\end{array}$ & $\begin{array}{l}\text { Breast } \\
\text { cancer } \\
\text { deaths }\end{array}$ & $\begin{array}{c}0.85 \\
\left(0.53^{-}\right. \\
1.36)\end{array}$ \\
\hline $\begin{array}{l}\text { Friedenreic } \\
\mathrm{h} \text { et al., } \\
2008\end{array}$ & Denmark & $\begin{array}{l}1231, \\
\text { Mean } 56 \\
\text { years old }\end{array}$ & $\begin{array}{l}\text { Breast } \\
\text { cancer } \\
\text { women } \\
\text { stage o-III }\end{array}$ & $\begin{array}{l}\text { I: High physical } \\
\text { activity } \\
\text { C: Low physical } \\
\text { activity }\end{array}$ & $\begin{array}{l}\text { Breast } \\
\text { cancer } \\
\text { deaths }\end{array}$ & $\begin{array}{c}0.79 \\
\left(0.53^{-1.17}\right)\end{array}$ \\
\hline $\begin{array}{l}\text { Hellmann } \\
\text { et al., } 2010\end{array}$ & Canada & $\begin{array}{l}528, \\
\text { Median } \\
66.9 \\
\text { years old }\end{array}$ & $\begin{array}{l}\text { Breast } \\
\text { cancer } \\
\text { women }\end{array}$ & $\begin{array}{l}\text { I: High physical } \\
\text { activity } \\
\text { C: Low physical } \\
\text { activity }\end{array}$ & $\begin{array}{l}\text { Breast } \\
\text { cancer } \\
\text { deaths }\end{array}$ & $\begin{array}{c}1.01(0.62- \\
1.63)\end{array}$ \\
\hline $\begin{array}{l}\text { Irwin et al., } \\
2011\end{array}$ & USA & $\begin{array}{l}2910, \\
\text { Median } \\
63.5 \\
\text { years old }\end{array}$ & $\begin{array}{l}\text { Breast } \\
\text { cancer } \\
\text { women } \\
\text { stage I, II- } \\
\text { IIIA }\end{array}$ & $\begin{array}{l}\text { I: High physical } \\
\text { activity } \\
\text { C: Low physical } \\
\text { activity }\end{array}$ & $\begin{array}{l}\text { Breast } \\
\text { cancer } \\
\text { deaths }\end{array}$ & $\begin{array}{c}0.61 \\
\left(0.35^{-}\right. \\
0.99)\end{array}$ \\
\hline $\begin{array}{l}\text { Jung et al., } \\
2019\end{array}$ & German & $\begin{array}{l}2042, \\
\text { Median } \\
62.9 \\
\text { years old }\end{array}$ & $\begin{array}{l}\text { Breast } \\
\text { cancer } \\
\text { women } \\
\text { stage I-IV }\end{array}$ & $\begin{array}{l}\text { I: High physical } \\
\text { activity } \\
\text { C: Low physical } \\
\text { activity }\end{array}$ & $\begin{array}{l}\text { Breast } \\
\text { cancer } \\
\text { deaths }\end{array}$ & $\begin{array}{c}0.64 \\
(0.46- \\
0.89)\end{array}$ \\
\hline
\end{tabular}


Ketaren et al./ The Effect of Physical Activity on Survival Life in Breast Cancer Patients

\section{a. Forest Plot}

Interpretation of the results of primary studies on the effect of physical activity on

survival of breast cancer survivors can be

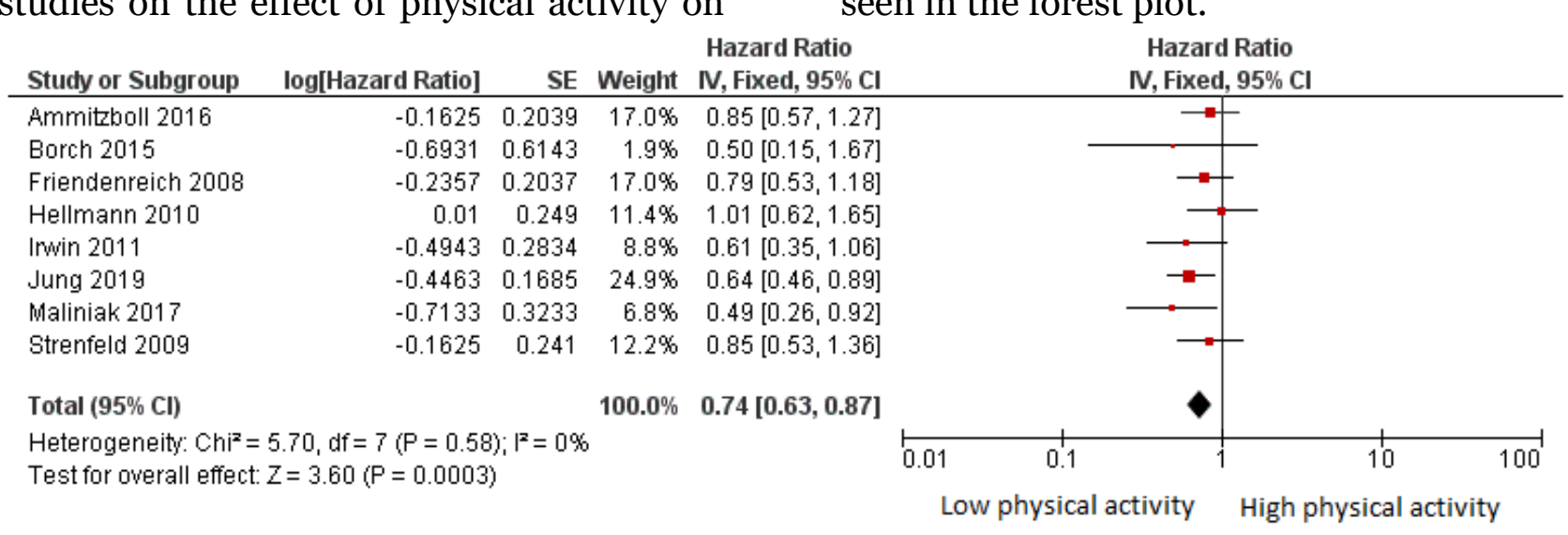

Figure 2. Forest Plot of the Effect of High Physical Activity on the Survival of Breast Cancer Survivors

Based on the results of the analysis in Figure 2, it can be seen that 8 articles reported that physical activity is one of the ways that affect the survival life of breast cancer survivors. The results of the metaanalysis in this study were homogeneous $\left(\mathrm{I}^{2}=0 \% ; \mathrm{p}=0.58\right)$. Thus, the Fixed Effect Model is used in data analysis in the forest plot. High physical activity can increase the survival of breast cancer survivors by $74 \%$ higher than low activity and it is statistically significant $(\mathrm{HR}=0.74 ; 95 \% \mathrm{CI}=0.63$ to $0.87 ; \mathrm{p}=0.0003)$.

\section{b. Funnel Plot}

A funnel plot is a diagram that illustrates the estimated effect size of each study on its estimate of accuracy which is usually a standard error.

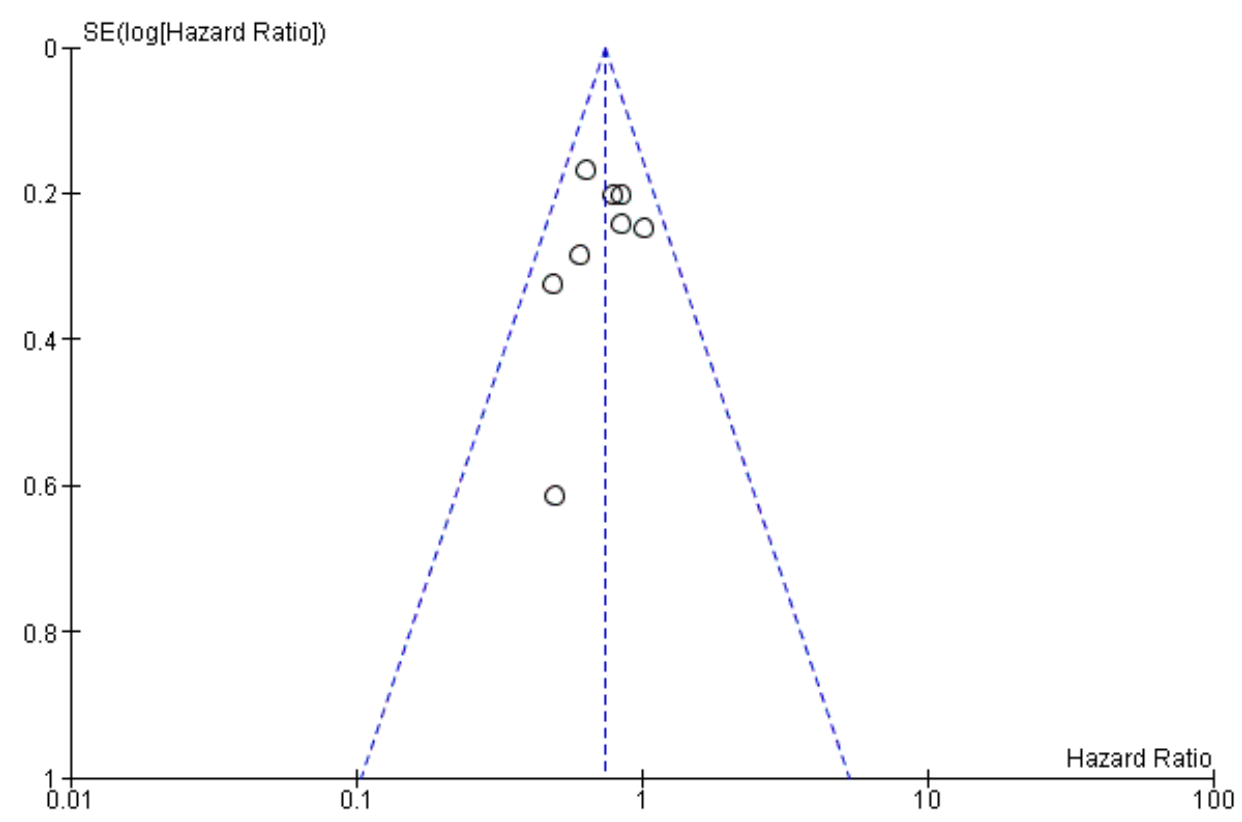

Figure 3. Funnel Plotof the Effect of High Physical Activity on the Survival of Breast Cancer Survivors 
Based on Figure 3, the plots on the right and left are not symmetrical each other and do not form an inverted shape. The left plot has a standard error of 0.6 , while the plot on the right has a standard error of <0.6. In addition, there is 1 plot on the left that is away from the vertical center line. This indicates that there is a publication bias in the study.

\section{DISCUSSION}

This study is a systematic and metaanalysis study that raised the theme of the effect of physical activity on the survival of breast cancer survivors. The independent variable analyzed was high physical activity. The dependent variable studied was the survival of breast cancer survivors. The results of the primary study conducted in a systematic study and meta-analysis showed an epidemiological study design with a larger sample, different demographic characteristics, thus providing a basis for concluding that physical activity has a statistical effect on the survival of breast cancer survivors.

This systematic study and metaanalysis study used studies that controls the confounding factor which can be seen from the primary study inclusion criteria used, namely the results of multivariate analysis in the form of adjusted hazard ratio (aHR). According to Murti (2018), confounding factor is the mixing of estimates of the relationship between exposure and the disease under study, by other factors related to both disease and exposure. Confounding factors affect the relationship or effect of exposure to the occurrence of the disease estimated (estimated) by the study is not the same as the relationship or effect that actually occurs in the target population, in other words, the study results are invalid (incorrect).

Estimates of the combined effect of physical activity on the survival of breast cancer survivors were processed using the RevMan 5.3 application with the generic inverse variance method. This method is used to analyze data in the form of rate, time-to-event, hazard ratio, ordinal scale, adjusted estimate, average difference or ratio of average.

The results of the systematic study and meta-analysis were presented in the form of a forest plot and a funnel plot. Forest plots provide an overview of information from each of the studies examined in the meta-analysis, and estimates of the overall results (Murti, 2018). A funnel plot is a diagram in a meta-analysis used to demonstrate possible publication bias. The funnel plot shows the relationship between the effect size of the study and the sample size or standard error of the effect size of the various studies studied (Murti, 2018). The funnel plot shows visually the amount of variation (heterogeneity) (Akobeng, 2005 in Murti, 2018). The funnel plot shows the relationship between the effect size of the study and the sample size of the various studies under study, which can be measured in a number of different ways (Murti, 2018).

Based on the article search, there were 8 articles on the cohort study as a meta-analysis source of the effect of physical activity on the survival of breast cancer survivors. The physical activity studied was high physical activity. According to Chlebowski (2013), physical activity is the most powerful and consistent lifestyle factor associated with breast cancer incidence and breast cancer recurrence. Consistent observational 
study evidence suggests that increased physical activity has a beneficial effect on breast cancer incidence and outcome. Breast cancer survivors can be counseled to avoid weight gain and lose weight if they are overweight or obese and increase or maintain low levels of physical activity.

Based on the results obtained from the forest plot article, it was shown that breast cancer survivors with high physical activity were $74 \%$ better than those who did low physical activity and significantly increased survival life $(\mathrm{HR}=0.74 ; 95 \%$ $\mathrm{CI}=0.63$ to $0.87 ; \mathrm{p}=0.0003)$. This is supported by Ibrahim and Al Homaidh (2010), which stated that post-diagnosis physical activity showed a $41 \%$ reduction in all causes of death $(\mathrm{HR}=0.59 ; 95 \% \mathrm{CI}=$ 0.53 to $0.65 ; \mathrm{p}=0.001$ ). Physical activity was shown to reduce all causes and diseases. On the other hand, the potential benefits of post-diagnosis of physical activity are more convincing. All levels of post-diagnosis physical activity reduced breast cancer mortality by about 30\% and decreased all-cause mortality by $41 \%$.

Gracia et al. (2014) reported that in 2003, the American Cancer Society published the first report to provide health care settings and guidelines for physical activity for people with cancer. The report suggests that cancer survivors follow cancer prevention guidelines (for example, at least 30 minutes of moderate to high physical activity at least 5 days per week above regular activity. 45-60 minutes of deliberate physical activity is preferred) is safe to do, even while undergoing treatment such as chemotherapy or radiation. For information, high activity is jogging/running, cycling faster than 10 miles per hour, heavy gardening (digging, hoeing), climbing, swimming, tennis (singles). This is in line with the research of Bertram et al. (2010) which stated that the risk of death was 53\% lower than those who did not do physical activity $(\mathrm{HR}=0.47 ; 95 \% \mathrm{CI}=0.26$ to $0.84 ; \mathrm{p}=$ 0.01). Physical activity is associated with a reduced risk of death. Women who used physical activity guidelines for aerobics at baseline had a $35 \%$ reduced risk of death compared with those who did not adhere to physical activity guidelines. Moderatehigh activity accounts for $80 \%$ of total activity. Women who fulfilled physical activity guidelines at baseline were slightly older, leaner, less likely to be post-menopausal, less likely to smoke or have previously smoked, and more likely to be white and have college degrees $(\mathrm{p}=$ 0.05) than those who do not fulfill the guidelines.

This is supported by the Troeschel et al. (2018) which stated that American Cancer Society guidelines for cancer sufferers recommend at least 150 minutes of moderate-intensity aerobic activity or 75 minutes each week. Despite the health benefits of physical activity, research shows that most cancer survivors are not active enough, with adherence to physical activity guidelines ranging from $17 \%$ to $47 \%$. This study is in line with research by Bradshaw et al. (2014) which stated that the survival among highly active women after diagnosis was (>9.0 MET h/week) compared with inactive women (o MET hours/ week) from all causes of death specifically for breast cancer $(\mathrm{HR}=0.27$; $95 \% \mathrm{CI}=0.15$ to 0.46 ). Cancer survivors should also engage in moderate or more intense muscle strengthening activities involving all major muscle groups for 2 or more days a week, as this can provide additional health benefits. In addition, to 
reduce adverse health effects, all adults and older adults should strive to do more than the recommended level of moderate to high physical activity (WHO, 2020).

The limitation in the study was that there was publication bias, language bias and the researcher only used 4 indexing databases (PubMed, Google Scholar, Science Direct, Springer Link) in finding primary study articles for meta-analysis so that the other search sources were ignored.

\section{AUTHOR CONTRIBUTION}

Enge Surabina Ketaren collected and selected the eligible articles, run Revman program for meta analysis, and wrote the paper. Bhisma Murti and Vitri Widyaningsih interpreted the results of metaanalysis.

\section{CONFLICT OF INTEREST}

None.

\section{FUNDING AND SPONSORSHIP}

There was no external fund.

\section{ACKNOWLEDGEMENT}

We thank to the researchers and open access journal providers.

\section{REFERENCE}

American Cancer Society (2019). Breast cancer facts \& figures 2017-2018. In Handbook of Evidence-Based Radiation Oncology. American Cancer Society. https://doi.org/10.1007/978-3319-62642-0_17.

Ammitzboll G, Søgaard K, Karlsen RV, Tjønneland A, Johansen C, Frederiksen K, Bidstrup P (2016). Physical activity and survival in breast cancer. European Journal of Cancer. 66: 6774. https://doi.org/10.1016/j.ejca.20-
16.07.010.

Beasley JM, Kwan ML, Chen WY, Weltzien EK, Kroenke CH, Lu W, Nechuta SJ, et al. (2012). Meeting the physical activity guidelines and survival after breast cancer: Findings from the after breast cancer pooling project. Breast Cancer Res Treat. 131(2): 637-43. https://doi.org/10.1007/s10549-0111770-1.

Borch KB, Braaten T, Lund E, Weiderpass E (2015). Physical activity before and after breast cancer diagnosis and survival - The Norwegian women and cancer cohort study. BMC Cancer. 15(1): 1-10. https://doi.org/10.1186/s12885-015-1971-9.

Bertram LAC, Stefanick ML, Saquib N, Natarajan L, Patterson RE, Bardwell W, Flatt SW, et al. (2011). Physical activity, additional breast cancer events, and mortality among earlystage breast cancer survivors: Findings from the WHEL study. Cancer Causes and Control, 22(3): 427-435. https://doi.org/10.1007/s10552-0109714-3.

Bradshaw PT, Ibrahim JG, Khankari N, Cleveland RJ, Abrahamson PE, Stevens J, Satia JA, et al. (2014). Postdiagnosis physical activity and survival after breast cancer diagnosis: The long island breast cancer study. Breast Cancer Research and Treatment. 145(3): 735-742. https://doi.org/10.1007/s10549-014-2966-y.

Chlebowski RT (2013). Nutrition and physical activity influence on breast cancer incidence and outcome. Breast, 22(2): S30-S37. https://doi.org/10.1016/j.breast.2013.07.006.

Friedenreich CM, Gregory J, Kopciuk KA, Mackey JR, Courneya KS (2009). Prospective cohort study of lifetime physical activity and breast cancer 
Ketaren et al./ The Effect of Physical Activity on Survival Life in Breast Cancer Patients

survival. Int J Cancer. 124(8): 19541962. https://doi.org/10.1002/ijc.24155.

Garcia DO, Thomson CA (2014). Physical activity and cancer survivorship. Nutr Clin Prac. 29(6): 768-779. https://dx.doi.org/10.1177\%2Fo88453361455 1969.

Globocan Observatory. (2020). Breast Cancer. Source: Globocan 2018. World Health Organization International Agency for Research on Cancer, 876, 2018-2019. http://gco.iarc.fr/today\%oAhttps://gco.iarc.fr/today/data/fa ctsheets/populations/900-world-factsheets.pdf accessed on September 2020.

Hellmann SS, Thygesen LC, Tolstrup JS, Gronbaek M (2010). Modifiable risk factors and survival in women diagnosed with primary breast cancer: Results from a prospective cohort study. European J Cancer Prev. 19(5): 366-373. https://doi.org/10.1097/CEJ.obo13e32833b4828.

Ibrahim EM, Al-Homaidh A (2011). Physical activity and survival after breast cancer diagnosis: Meta-analysis of published studies. Med Oncol. 28(3): 753-765. https://doi.org/10.1007/s12032-010-9536-x.

Irwin ML, McTiernan A, Manson JAE, Thomson CA, Sternfeld B, Stefanick ML, Wactawski-Wende J, et al. (2011). Physical activity and survival in postmenopausal women with breast cancer: Results from the women's health initiative. Cancer Prevention Research. 4(4): 522-529. https://doi.org/10.1158/1940-6207.CAPR-10-0295.

Jung AY, Behrens S, Schmidt M, Thoene K, Obi N, Husing A, Benner A, Steindorf K, Chang-Claude J (2019). Pre-to postdiagnosis leisure-time physical activity and prognosis in postmenopausal breast cancer survivors. Breast Cancer Research. 21(1): 1-11. https://doi.org/10.1186/s13058-019-1206o.

Kementerian Kesehatan RI (2017). Rencana aksi nasional penyakit tidak menular (National action plan for non-communicable diseases) 2015-2019. Kementerian Kesehatan RI.

Maliniak ML, Patel AV, McCullough ML, Campbell PT, Leach CR, Gapstur SM, Gaudet MM (2018). Obesity, physical activity, and breast cancer survival among older breast cancer survivors in the cancer prevention study-II nutrition cohort. Breast Cancer Research and Treatment. 167(1): 133-145. https://doi.org/10.1007/s10549-0174470-7.

Murti B (2018). Prinsip dan Metode Riset Epidemiologi. Edisi ke 5 (Epidemiological Research Principles and Methods. 5th edition). Surakarta: Program Studi Ilmu Kesehatan Masyarakat.

Speck RM, Courneya KS, Mâsse LC, Duval S, Schmitz KH (2010). An update of controlled physical activity trials in cancer survivors: A systematic review and meta-analysis. J Cancer Surv. 4(2): 87-100. https://doi.org/10.1007/s11764-009-0110-5.

Sternfeld B, Weltzien E, Quesenberry CP, Castillo AL, Kwan M, Slattery ML, Caan BJ (2009). Physical activity and risk of recurrence and mortality in breast cancer survivors: Findings from the LACE study. Cancer Epidemiology Biomarkers and Prevention. 18(1): 87-95. https://doi.org/10.1158/1055-9965.EPI-08-0595.

Troeschel AN, Leach CR, Shuval K, Stein KD, Patel AV (2018). Physical activity in cancer survivors during "Re-Entry" 
Ketaren et al./ The Effect of Physical Activity on Survival Life in Breast Cancer Patients

following cancer treatment. Preventing Chronic Disease. 15(5): 1-10. https://doi.org/10.5888/pcd15.17027

7.

WHO (2020). Breast cancer survival. World Health Organization. https://www.cancer.org/cancer/breast-cancer/- understanding-a-breast-cancer-diagnosis/breast-cancer-survival-rates.html.

WHO (2020). Physical activity. World Health Organization. https://www.who.int/news-room/fact-sheets/detail/physical-activity. 